Pamiętnik Literacki 2017, 4, s. 105-118
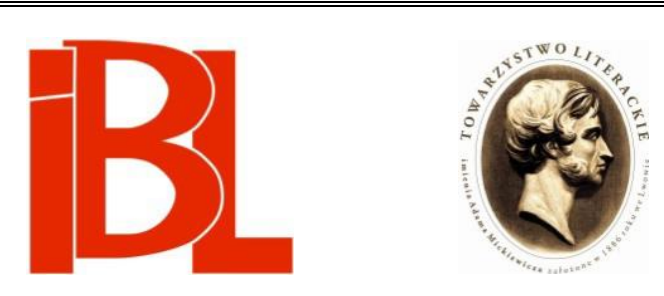

\title{
Zuzanna i starzec. Kenotyczny wymiar pisarstwa Jerzego Pilcha
}

Adam Regiewicz 
Pamiętnik Literacki CVIII, 2017, z. 4, PL ISSN 0031-0514

DOI:10.18318/pl.2017.4.7

ADAM REGIEWICZ Akademia im. Jana Długosza, Częstochowa

\section{ZUZANNA I STARZEC KENOTYCZNY WYMIAR PISARSTWA JERZEGO PILCHA}

Grabaż [!] to skończony matoł, on się skończył, nim się zaczął [...] $]^{1}$.

Lektura minipowieści Jerzego Pilcha Zuza albo czas oddalenia (czy - jak sugeruje komentarz odautorski - Rękopis ukryty $w$ bucie) pozostawia nieodparte wrażenie, jakby się miało do czynienia z książką, którą wcześniej już się czytało. Starzejący się, 60-letni mężczyzna zakochuje się w młodej dziewczynie parającej się najstarszym zawodem świata, a przy okazji rozpamiętuje swoje poprzednie związki - mniej lub bardziej udane. Jest to postać, z którą Pilch nie potrafi się rozstać od początku kariery pisarskiej. Podobnie jak Marek Koterski, przedstawiający za pomocą filmu swoje małe i wielkie kryzysy egzystencjalne, wykreował postać Adama (niekiedy Michała) Miauczyńskiego, tak też Pilch od czasu Wyznań twórcy pokątnej literatury erotycznej opowiada wciąż tę samą historię bohatera doświadczającego porażki życiowej i trwającego w permanentnym kryzysie. Pomimo upływu lat poszukuje on sensu (a właściwie zmaga się $\mathrm{z}$ bezsensem):

Nastał rok 1980, ja zaś nadal nie byłem pisarzem. Nawiedzały mnie demony lenistwa i nałogów, a w głębi duszy, serca i ciała zauważyłem pierwsze objawy zmęczenia² ${ }^{2}$

I chociaż od tamtego wyznania minęły trzy dekady, sytuacja egzystencjalna postaci wykreowanej przez Pilcha nie zmieniła się za wiele. Gdy przyjrzeć się dokładnie, wewnętrzna busola wyznacza drogę pomiędzy kobietami, alkoholem i pisaniem (językiem), które stają się dla bohatera zarazem nadzieją, jak i traumą.

Dziesięcioleciami chlałem niczym bydlę nieczyste, przez dziesięciolecia byłem pijany jak bydlę nieczyste i w ciągu kilku godzin bez zasługi wytrzeźwiałem. Bez zasługi? Nie, radykalnie odrzucam wszelką kokieterię. Moją zasługą była moja rozpacz, moją zasługą były moje modlitwy i moją zasługą jest moja miłość ${ }^{3}$.

Podążając za wskazanymi przez autora tropami, warto podjąć refleksję nad relacją patrzenia i pisania, które najpewniej mają wspólny mianownik - oddalenie.

1 Strachy Na Lachy, I Can't Get No Gratisfaction. Na stronie: strachynalachy.art.pl/teksty/i-cant-get-no-gratification/ (data dostępu: 3 X 2017).

2 J. Pilc h, Kraków. W: Wyznania twórcy pokątnej literatury erotycznej. Londyn 1999, s. 7.

3 J. Pilch, Pod mocnym aniołem. Kraków 2000, s. 261. 


\section{Zuzanna i satyr}

Skojarzenie opowieści Pilcha $z$ biblijną historią Zuzanny wydaje się oczywiste. Od tej konotacji nie ucieka nawet on sam:

Zuza i bez starców jest wystarczająco perwersyjna. Inaczej: to imię nigdy całkowicie nie obywa się bez lubieżnych podglądaczy, ich cienie są gdzieś w pobliżu, drzemią, śpią, nie żyją - na każdy sygnał gotowi do zmartwychwstania. Ich gapienie się mocniejsze od śmierci. Gapię się jak oni. Jest na co. $[\mathrm{Z} 16-17]^{4}$

Pomimo wypowiadanych przez narratora zapewnień, iż nie o „tę” Zuzannę chodzi, trudno oprzeć się wrażeniu, że biblijny kontekst jest w pewien sposób narracją mityczną, na której nadbudowuje on swoją opowieść. Zresztą nawiąania do Pisma Świętego wszędzie się tu pojawiają: począwszy od tytułowego „czasu oddalenia” odnoszącego się do Koheletowego (3, 1-15) rozważania, że każda rzecz ma swoją

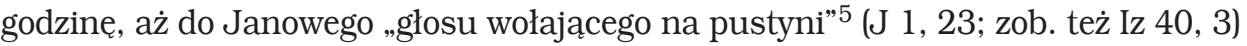
jako metafory pisania. Mniejsza jednak o aluzje i konteksty. Kluczem jest Zuzanna.

Na pierwszy rzut oka między biblijną Zuzanną a powieściową Zuzą - poza imieniem - brakuje głębszych powiązań, choć od początku motyw scalający stanowią piękno i powab dziewczęcego ciała. Bohaterka mądrościowej opowieści o sądzie proroka Daniela (Dn 13, 1-64) jest bardzo urodziwa i bogobojna, woli raczej umrzeć, niż zgrzeszyć przeciw Bogu. Zuza, podobnie powabna, oddaje swe ciało klientom jako Sonia, Bella, Żaneta czy Olga. Jeśli ta pierwsza skrywa nagość, druga ją eksponuje, gdy biblijna Zuzanna ucieka przed wzrokiem podglądających ją starców, zakrywając się - Pilchowa Zuza wystawia się na pożądliwe spojrzenia mężczyzn, odkrywając się. Zuzanna w kapieli to uosobienie naturalnego piękna, rozbierająca się Zuza to krew i mleko, hialuron i silikon - zreszta w obronie tego syntetycznego piękna narrator będzie występował na kartach książki wielokrotnie („Ciało stało się szatą, której model i krój można zmieniać, że o drobnych poprawkach 〈krawieckich〉 nie wspomnę", Z 18). A jednak, gdyby zagłębić się w egzegezę opowieści o biblijnej Zuzannie, można odkryć zadziwiająco wiele zbieżności z historią o frywolnej Zuzie.

Dołączoną do końcowej partii Księgi Daniela opowieść odczytuje się w tradycji jako alegorię losów Izraela, a właściwe jego południowej części - „córek judzkich”, które w czasach króla Antiocha były kuszone wchodzeniem w nieczyste relacje z otaczajacymi je idolami. Historia kultury nie pozostawia złudzeń co do tego, że większość wierzeń pogańskich tego okresu wiązała się z praktykami seksualnymi, choć opisaną w omawianej księdze sytuację domniemanego uprawiania nierządu należy traktować metaforycznie jako odejście od Prawa Mojżeszowego. Samo imię Zuzanna wywodzi się z hebrajskiego szoszannah, co oznacza lilię. Przywołana w ten sposób alegoria czystości i cnoty może być oczywista wobec postawy, jaką zajmuje bohaterka biblijnej opowieści, ale nie udaje się jej zrozumieć w wypadku Zuzy bez odniesienia do pism proroka Ezechiela, u którego również pojawia się ta metafora.

4 Skrótem Z odsyłam do: J. Pilch, Zuza albo czas oddalenia. Kraków 2015. Liczby po skrócie oznaczają stronice.

5 Tu i w całym artykule, jeśli nie zaznaczono inaczej, cytując z Biblii korzystam z wyd.: Pismo Święte Starego i Nowego Testamentu $w$ przekładzie z języków oryginalnych. Oprac. Zespół Biblistów Polskich [...]. Biblia Tysiaclecia. Wyd. 5, na nowo oprac. i popr. Poznań 2003. 
W wymienionej księdze (Ez 16, 6-14) Szoszannah to dziewczyna szamocząca się we krwi, porzucona i poraniona, którą Oblubieniec okrywa płaszczem, by zasłonić jej nagość przed pożądliwymi oczami. Dramatyczna sytuacja młodej kobiety, która dopiero co nabiera niewieścich kształtów, jest symptomatyczna dla młodego narodu Izraela, niszczonego przez okoliczne ludy. Figura Izraela jako Oblubienicy cudzołożącej $z$ innymi bogami występuje $z$ dużą intensywnością na kartach Pisma Świętego ${ }^{6}$. Tak też jawi się Szoszannah, gdy spotyka na swej drodze Oblubieńca, mówiącego:

Uczyniłem cię jak kwiat polny [lilię Szaronu - A. R.]. Rosłaś, wzrastałaś i doszłaś do wieku dojrzałego. Piersi twoje nabrały kształtu i włosy twoje stały się obfitsze. Ale byłaś naga i odkryta. [Ez 16, 7]

Od tego momentu zmienia się wszystko, Oblubieniec bowiem ociera krew z kobiety, obmywa ją wodą, naciera olejkiem, odziewa szatami królewskimi i przyozdabia w klejnoty - Szoszannah staje się Jego własnością.

Działanie zmierzające do uczynienia „swoją” jest także udziałem bohatera powieści Pilcha, który w podobny sposób próbuje „ubierać” Zuzę, nakładając na nią swoje fantazje: „Ubierz się jak uczennica - prosiłem. Przychodziła w przyciasnej białej bluzczynie, nie pytajcie, na ile guzików zapiętej” (Z 27). Nieskrywany podziw dla urody dziewczyny wyraża w poemacie:

Usta Zuzy jako sznur hialuronowy - dokładnie odmierzona dawka, jest pełniej, ale bez karykaturalnego rozdęcia. Piersi Zuzy - arcydzieło chirurgii plastycznej. [...] Zawsze twierdziłem i nadal twierdzę, że lepsze piękno syntetyczne niż brak naturalnego. Lepsza cielesna konstrukcja niż anatomiczna zapaść. [Z 17]

Podobną frazę, odnosząca się do Ezechielowej Szoszannah, można odnaleźć w Pieśni nad Pieśniami (7, 7-10):

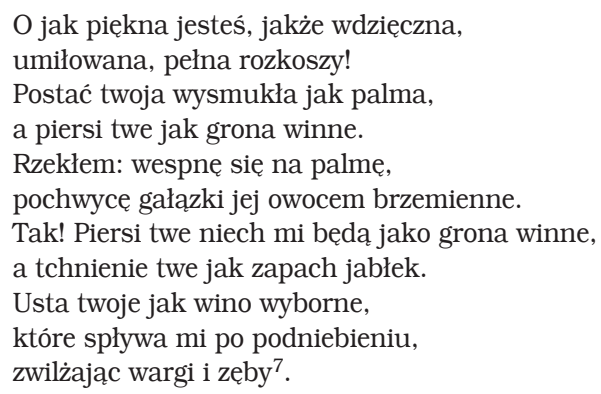

6 Najbardziej dotkliwą historię, ukazująca sytuację narodu wybranego uprawiającego nierząd z innymi bogami, opowiada prorok Ozeasz, który poślubia nierządnicę. Przyjmuje ją pod swoim dachem, ta rodzi mu dzieci, a potem odchodzi, by ponownie wracać. Sytuacja Ozeasza jest alegorią Izraela i jego relacji z Bogiem.

7 Zob. też fragment wcześniejszy (PnP 7, 2-6):

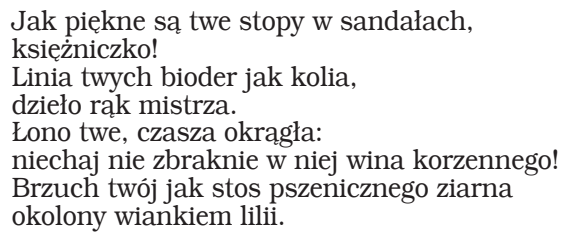


Tak zatem biblijna Zuzanna nie tyle jest cnotliwa ze swej natury, ile otrzymuje z powrotem pierwotną niewinność ze względu na Oblubieńca - Boga. O odzyskanej przestrzeni relacji człowieka i Boga przypomina inna przestrzeń - ogród, w którym dzieje się scena z Księgi Daniela. Ten trop interpretacyjny potwierdzałaby lektura midraszowa, która w całym tym zamieszaniu ze starcami pozwala widzieć reminiscencję wydarzeń $z$ ogrodu Eden. Tym razem jednak Zuzanna nie daje się zwieść jak pramatka Ewa przebiegłemu kusicielowi, nie wchodzi w dialog z szatanem (nb. tradycja wczesnochrześcijańska i ikonografia Kościoła wschodniego przedstawiały go pod postacią starca), znając już konsekwencje złamania przymierza z Bogiem.

Dla Zuzy Pilcha ów ogród jest raczej ogrodem rozkoszy. Miłość do jednego Oblubieńca niepokojąco przypomina jej więzienie, stąd podobna do zachowania biblijnej Zuzanny niechęć do bycia pochwyconą. Jednak strategie przyjęte w związku z pułapkami, jakie zastawia na bohaterki wzrok męski, zdecydowanie się różni: jeśli Zuzanna ukryła swoje nagie ciało pod płaszczem przed spojrzeniami lubieżnych starców, to „Zuza nie była ani mieszczką, ani artystką. Lubiła pozować - przeważnie nago, przeważnie do pokątnych kalendarzy" (Z 95). Eksponowanie nagości wydaje się z jej strony przemyślaną strategią ukrywania tego, co prawdziwe. W końcu znika z oczu bohatera - wyjeżdża, wyrywa się, porzuca go, stając się pożądanym fantazmatem, zaledwie wyobrażeniem, ale jakże żywym: „Jej nogi, jej korpus, jej głowa. Jakie widmo? Żywa, z krwi i kości dupa!” (Z 115). Do tej erotycznej fantazji trzeba będzie powrócić.

Warto zatrzymać się jeszcze przy aktorach reprezentujących drugą stronę spektaklu - przy starcach czy bohaterze-narratorze, którzy tak bardzo próbowali uchwycić wzrokiem Zuzannę vel Zuzę. Fragment z Księgi Daniela opowiada o rosnącej pożądliwości dwóch starców, długi czas skrywanej za kurtuazyjnymi wizytami u Joakima, męża Zuzanny. Droga nieprawości zaczyna się od spojrzenia, mówi prorok: obaj starcy „Zatracili swój rozsądek i odwrócili swe oczy, zaniedbując spoglądania ku Niebu [...]" (Dn 13, 9), karmiąc swoją duszę widokiem Zuzanny, aż stała się ona ich obsesją. Jeśli przypomnimy też, że wcześniej zostali oni wybrani sędziami ludu, wzrok stanie się w tej opowieści metafora „męskiego spojrzenia”, łączącego w sobie władzę, wyniosłość i pożądliwość. Do analizowanego fragmentu z Księgi Daniela odnosi później swoje słowa Chrystus w Kazaniu na Górze, gdy mówi, że „Każdy, kto pożądliwie patrzy na kobietę, już się w swoim sercu dopuścił z nią cudzołóstwa” (Mt 5, 28); Jan Ewangelista zaś, który w liście pisze o „pożądliwości oczu", wiąże spojrzenie nie tylko $z$ ciałem, ale przede wszystkim ze stanem pychy - uczuciem wyższości (1 J 2, 16).

Piersi twe jak dwoje koźląt,

bliźniąt gazeli.

Szyja twa jak wieża ze słoniowej kości.

Oczy twe jak sadzawki w Cheszbonie,

u bramy Bat-Rabbim.

$\langle\ldots \ldots \ldots \ldots . . \ldots\rangle$

Nos twój jak baszta Libanu,

spoglądająca ku Damaszkowi.

Głowa twa 〈wznosi się〉 nad toba jak Karmel,

włosy głowy twej jak królewska purpura,

splecione $\mathrm{w}$ warkocze. 
Podobnie w powieści Pilcha - historia pożądania zaczyna się od spojrzeń, a nawet wprost od podglądania kapiących się studentek. Marzenie erotyczne, jeszcze nie tak dawno skrzętnie skrywane przed opinia publiczną, wraz z modernistycznymi fantazmatami wkroczyło na salony. Bohater zamawia usługę prostytutki, ta zaś obezwładnia go swym wyglądem - nie rozmową ani dotykiem, ale właśnie powierzchownością. I chociaż sam deklaruje, że nie należał nigdy do podglądaczy i że studentki Akademii Rolniczej były podglądane nie przez niego, lecz przez kolegów, oraz że dotąd nie widział rozbierającej się kobiety, to jednak upozowane zdjęcie Zuzy (vel Soni, vel Belli, vel Olgi), ze wszystkim tym, co na owym zdjęciu sztuczne - tak bardzo, że aż prawdziwe - budzi w nim zainteresowanie. Pociaga go jej umiejętność przybierania różnych póz: bycia zarazem drapieżną i uległą, zmysłową Żanetą i zagubioną Olgą, porywającą „brunecicą" i delikatną blondynką, makijaż i silikon w najlepszym wydaniu. W sposobie zachowania bohater przypomina bardziej voyeura niż oszalałego z miłości kochanka:

Kręcił mnie jej [tj. Zuzy] fach, kręciło wyobrażenie kilku otaczających ją równocześnie mężczyzn. Przyglądałem się im uważnie, każdy był mną i tu było sedno mojej ciemności. [...] Można powiedzieć, iż mam wyraźną skłonność do uprzedmiotowiania kobiet. [Z 22]

Trudno oprzeć się wrażeniu, że tak sytuacja przedstawiona u Pilcha, jak i biblijna scena z Zuzanną podglądaną w kąpieli charakteryzują się obrazowością w dużym stopniu filmowa ${ }^{8}$. W kreowanym spektaklu świat jest wyraźnie podzielony na tych, którzy patrza, i na tych, którzy zostali przez to spojrzenie uprzedmiotowieni ${ }^{9}$. Zdecydowanie to męskie spojrzenie narzuca kobiecie jej miejsce, sytuuje ją w konkretnym kontekście erotycznym, poddańczym. Kobiety zaś przedstawiane są w sposób silnie wrażeniowy, oddziałując na oglądającego jako rodzaj atrakcji. Ich status ogranicza się do bycia przedmiotami obserwacji, podczas gdy to mężczyźni stanowią stronę aktywną - podglądaczy, którzy penetrują wzrokiem, oceniają, ślizgają się po powierzchni dostępnych im ciał. A jednak obecność kobiety jest nieodłącznym elementem widowiska. John Berger zwraca uwagę: „Upraszczając, można powiedzieć: mężczyźni działają, a kobiety objawiają się. Mężczyźni patrzą na kobiety. Kobiety patrzą na siebie, będąc przedmiotem oglądu"10. Kobiety nie wiążą zatem pożądania $z$ tym, co dostrzegalne, ale doznawana przez nie przyjemność polega na byciu widzianymi. Zdaje sobie sprawę z pułapki pornograficznej narrator opowieści Pilcha, kiedy pisze:

Dekolty, bielizna, mini, wszelkie ciuchy niezasłaniające, a obnażające do łask przywrócone. [Z 24]

Zuza zwracała uwagę. Głównie dekoltami. Skądinąd trudno się dziwić - nie po to ufundowała sobie za ciężkie pieniądze fenomenalny biust, by teraz go skrywać. [Z 26]

8 Warto tu przypomnieć wykorzystaną w filmie Diabelskie sztuczki (L'imbroglio nel lenzuolo) A. A r a u a z 2010 roku, mówiącym o początkach kina, scenę kapieli biblijnej Zuzanny, która przyciagała tłumy miejscowych ze względu na ukazywaną tam nagość.

9 Zob. L. Mulv e y, Przyjemność wzrokowa a kino narracyjne. W: Do utraty wzroku. Wybór tekstów. Red. K. Ku c, L. Th om p s o n. Kraków-Warszawa 2000, s. 39 (przeł. J. M a ch).

10 J. B erger [i in.], Sposób widzenia. Na podstawie cyklu programów telewizyjnych BBC Johna Bergera. Przeł. M. B ry l. Poznań 1997, s. 55. 
Tak bohater, jak i Zuza pozostają we władzy spojrzenia. Ten pierwszy jest przekonany, że to on decyduje, co i jak podgląda, w rzeczywistości manipuluje nim narzucające się wyuzdanie. Podobnie Zuza, uprzedmiotowiona przez spojrzenia męskie, nie potrafi patrzeć na siebie inaczej, sama straciła już tożsamość, wyobrażenie przejęło kontrolę nad prawdziwym ,ja”:

Zuza może się ubrać w wór pokutny, może ostrzyc przedłużane włosy, może nie mieć makijażu, może tysiąc innych maskujących albo demaskujących czynności wykonać, matula i tak ją przejrzy. [Z 57]

Druga (z trzech pojawiających się w całej książce) figura: Matki, stanowi kolejną kluczową dla rozważań postać. Ta 86-letnia kobieta jest pewnego rodzaju miernikiem przyzwoitości. Nic dziwnego, że bohater $z$ takim lękiem przyjmuje próbę zaprezentowania Zuzy - matka oddzieli prawdę od fałszu, ziarno od plew. Wydaje się, że z powodu wieku, ale też i ze względu na trzymanie się tradycji ewangelickiej reprezentuje ona świat wartości, jakiego już nie ma - świat, w którym granice rysowały się ostro, gdzie czerń i biel nie wchodziły w odcienie szarości. Lecz matka to także macierz, macica, to miejsce, do którego chca powrócić ludzie zmęczeni życiem. To tutaj „stary” człowiek może stać się „nowy”. W tradycji Kościoła pierwotnego utożsamiano sadzawkę chrzcielną z łonem kobiecym (widać to szczególnie na ikonie Maryi Dziewicy - w Jej łonie dojrzewa mały Chrystus), noszącym „nową naturę”. Tu dokonuje się prawdziwa metanoia, przemiana „starego” w „nowe”, jak mówi Pismo Święte: w wodach chrztu musi umrzeć „stary człowiek”, by mógł narodzić się alter Christus. Prawdopodobnie $z$ tego powodu bohater tak się lęka spotkania Zuzy z matką, która od razu odkryje, z kim ma do czynienia. Narodzinom „nowego" winna towarzyszyć śmierć i chyba dlatego w perspektywie tego spotkania myśli on o samobójstwie?

\section{Schodzenie, czyli kenoza}

Droga do śmierci jest drogą kenozy, czyli ogołocenia. Przywołany obraz sadzawki chrzcielnej - łona Kościoła, w którym rodzi się „nowy człowiek”, domaga się jednak dopełnienia. Sadzawkę, zgodnie z tradycją, okalają stopnie prowadzące w dół. Ich liczba - siedem - oznacza kolejne szczeble odkrywania prawdy o sobie. Chrześcijanin bowiem to ktoś, kto ma światło na swoją sytuację egzystencjalną, tzn. zna prawdę o sobie. W tym pomagał w Kościele pierwotnym długi, kilkuletni katechumenat, podczas którego kandydat do chrztu poznawał pułapki, jakie czekają na sprawiedliwego (Ps 34, 20), a są skrywane za ułuda grzechów. Towarzyszace owemu procesowi zstępowanie do wód chrzcielnych ma wyrażać powolne odzieranie z tego, co jest „stara naturą" człowieka - z pychy, zarozumialstwa, pożądliwości, nienasycenia, złości, zazdrości, lenistwa - by w końcu utopić w owych wodach (wodach śmierci) to, co wymaga unicestwienia. $Z$ sadzawki wychodził „nowy człowiek", który dzięki łasce sakramentu mógł odpowiadać na powaby grzechu cnotami: pokora, wstrzemięźliwością, hojnością, łagodnością itd.

Koncepcja chrześcijaństwa kenotycznego wywodzi się z chrystologii wyrażonej w Liście do Filipian (2, 6-7), w którym św. Paweł mówi:

[Chrystus] istniejąc w postaci Bożej, nie korzystał ze sposobności, aby na równi być $z$ Bogiem, 


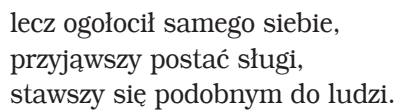

Ukazane tu uniżenie się i ogołocenie stają się podstawą przemiany świata zwycięstwa życia nad śmiercią. Kenoza Jezusa Chrystusa, w której odbija się zapowiadana przez proroka Izajasza postawa Cierpiącego Sługi Jahwe, jest początkiem drogi wyzwolenia, jaką Bóg przewiduje dla człowieka. Teologia kenotyczna podkreśla w tym miejscu charakterystyczny ruch w dół samego Boga, który odwraca swoją Boskość, stając się podatnym na cierpienie ze względu na przyjęte ciało. Ludzka postać Chrystusa stanowi pierwszy stopień kenozy Boga. Jeden z rosyjskich teologów - Aleksandr Buchariew - stwierdza, że ów proces towarzyszy Jezusowi przez całe życie: od nieświadomości w łonie Maryi, jako stworzenie noszącej swego Stwórcę, przez podporządkowanie się Prawu, które On sam nadał i wypełnia, wzrastanie w mądrości, niewiedzę, aż po poczucie osamotnienia w Ogrodzie Oliwnym, na krzyżu i wreszcie śmierć za ludzkie grzechy ${ }^{11}$. Chrystus - zgodnie z nauczaniem Kościoła - staje się grzechem i przekleństwem, dobrowolnie przyjmując postać sługi.

Wczytując się w zastosowane przez św. Pawła wyrażenia „ogołocić” i „uniżyć”, można zauważyć, że używa się ich w kontekście utraty mocy czy siły. Rezygnacja z władzy, jaką Chrystus posiada, czyni Go niewolnikiem tejże władzy, systemu czy Prawa. W owym poddaniu się podobny jest On do człowieka - aż do śmierci, przypominającej największe zniewolenie: haniebnej śmierci na krzyżu, zarezerwowanej dotąd dla barbarzyńców. $Z$ drugiej strony, sformułowanie „uniżył samego siebie” odnosi się do postaci sługi z przywoływanego już fragmentu z Księgi Izajasza, w którym zobrazowana jest postawa posłuszeństwa Bogu do końca ${ }^{12}$. Wpisana w tę figurę pokora stanowi dla świata starożytnego coś całkowicie obcego i niezrozumiałego, godnego pogardy. Pokorę i uniżoność, szczególnie w świecie rzymskim, traktowano jako przejaw bezradności czy wręcz tchórzostwa, stąd kenoza Chrystusa jest tak bulwersująca dla Żydów i pogan, dla jednych jest zgorszeniem (to efekt odwrócenia się Boga od tego, kto zostaje zmiażdżony cierpieniem), dla drugich głupota (wyrazem szaleństwa) (1 Kor 1, 23).

Dobrowolne ogołocenie się i samoograniczenie się Boga w rzeczywistości stanowi dla człowieka drogę zbawienia. Kościół w uniżeniu Chrystusa widzi odpowiedź na pragnienie człowieka, by samostanowić o sobie, by sprawować władze - szczególnie tę wyrażoną poprzez rozum, ludzką mądrość, wydawanie sądów. Dlatego święta pokora Chrystusa prowadzi człowieka do jego głębi. Poniekąd sytuacja uniżenia ociera się o tajemnicę duchowej nicości, ale nadal pozostaje złączona $\mathrm{Z}$ istota osoby, która przyjmuje takie stanowisko.

Zarysowane tu kwestie bliskie sa postawom bohaterów narracji Pilcha, który rozpisuje sytuację kenozy na głosy. Towarzyszy im poczucie znikomości:

11 Podaję za: W. H ry n i e w i c z, Dramat Boskiego uniżenia. Zapomniany rozdział chrystologii prawostawnej. „Znak” 1998, nr 521, s. 77.

12 Zob. B. Byrne, List do Filipian. W zb.: Katolicki komentarz biblijny. Red. nauk. wyd. oryg. R. E. Brown, J. A. Fitzmyer, R. E. Murphy. Red. nauk. wyd. pol. W. Chrostowski. Przeł. K. Bard ski [i in.]. Warszawa 2004, s. 1405. 
Byłem kruchym naczyniem, złotym kubkiem, blaszaną manierką uczynioną z blachy wytopionej w hucie imienia Lenina, szklanką z krośnieńskiego szkła, filiżanką z Ćmielowa ${ }^{13}$.

Postaci odczuwają marność swej egzystencji. Naznaczone pascalowskim drżeniem, przechowują strzępki przeżyć czy emocji „w naczyniach glinianych” (2 Kor 4, 7). Ponadto nie ukrywają, że ich konstytucja moralna jest dość nikła. „Strach, fałsz, zakłamanie, tchórzostwo - wszystkie te ciemne muzy" 14 inspirują działania bohaterów Pilcha, nawiedzają ich „demony lenistwa i nałogów, a w głębi duszy, serca i ciała [...]"15 pojawia się wszechogarniające poczucie zmęczenia. W tym sensie w powieści Zuza albo czas oddalenia narrator eksponuje doświadczenie starości jako sytuację egzystencjalnej (ale i społecznej czy kulturowej) niemocy. Czytamy:

Facet po sześćdziesiątce opowiadający o swych wzlotach uczuciowych to jest żenada. [...] Postna starość ogólnoświatowa w zasadzie nie przewiduje dla mnie dymania w żadnej postaci. [Z 10-11]

Za tą prześmiewczą postawą ukrywa się jednak dramat człowieka, który doświadcza niemożności kochania (i bycia kochanym). Jego działania, zmierzające najpierw do pochwycenia, ujarzmienia, usidlenia Zuzy (poprzez wzrok, potem przez pieniądze, wreszcie poprzez jakąś namiastkę związku, a nawet małżeństwo) podszyte są strachem. Lęk bohatera przed odrzuceniem Zuzy przez matkę, rozpoznającą w dziewczynie jej prawdziwą naturę, przed ośmieszeniem się, ale najbardziej - przed byciem samotnym, to niemal lęk Kafkowski przed sądem, na którym wszyscy musimy pojawić się indywidualnie. W tym właśnie kontekście można odczytywać fragment odnoszący się do rozważań narratora powieści Zuza albo czas oddalenia na temat samobójstwa jako próby rozładowania rodzącej się w nim frustracji:

wracam do siebie i mam poczucie, iż skończył się kolejny pełen udręki dzień. Kiedy okoliczności życiowe (pralnia albo bank) zmuszają mnie do przedłużenia porannych zajęć do dziesiątej, jestem w bezwyjściowej sytuacji i wiem, że zmarnowanego czasu nie odzyskam nigdy. Na dodatek najbliższe godziny to będzie czas widziadeł i strachu. [Z 85]

Cytat ten wskazuje na drugi aspekt kenotyczny. Sytuacja życia, codzienność, w jakiej zanurzeni są bohaterowie, także nosi znamiona kryzysu:

Budziłem się w pustce, pustka była wkoło i ja byłem pustką. [...] czułem się tak, jakbym był wszystkiego pozbawiony ${ }^{16}$.

Zbliżając się do trzydziestki, postanowiłem wyciagnać z młodzieńczych marzeń ostateczne i rzeczywiste konsekwencje. Niczego jednak nie umiałem. Nie rozumiałem świata ${ }^{17}$.

Bezsilność i doświadczenie bezradności, z jakimi postaci z powieści Pilcha wchodza w rzeczywistość, bliskie sa poczuciu ogołocenia, rozumianego jako utrata mocy, tego wszystkiego, co czyni człowieka panem życia - przestają sprawować jakąkolwiek kontrolę nad nim, aż zaczyna być ono koszmarem:

J. Pilc h, Spis cudzołożnic. Proza podróżna. Londyn 1993, s. 90.

Ibidem, s. 55.

Pilch, Kraków, s. 7.

J. Pilc h, Monolog z lisiej jamy. Kraków 1996, s. 17.

Pilch, Kraków, s. 13. 
Tyle razy chciałem opisać historię człowieka podnoszącego się z upadku, tyle razy, niezliczoną ilość razy, że gdy wreszcie niepojętym zbiegiem okoliczności sam podnosiłem się $z$ upadku, gdy sam byłem podnoszony $\mathrm{z}$ upadku, gdy czyjaś widzialna albo niewidzialna dłoń wyjmowała mnie $\mathrm{z}$ przepastnego dołka, nie umiałem za własnym podnoszeniem się nadążyć. Nie jestem w stanie opisać własnego wyzwolenia jako serii przekonujących wydarzeń, nie potrafię dać ewolucyjnej historii własnego zmartwychwstania - daję jedynie te epifaniczne wersy. Ale też zmartwychwstanie moje było niczym epifania, było niczym haiku, było niczym jeden nieomylny jak błyskawica wers ${ }^{18}$.

We fragmencie tym odbija się jeden z podstawowych artykułów wiary chrześcijańskiej o zejściu Chrystusa do piekła, skąd wyciaga On tych, którzy z powodu grzechu i zamkniętych niebios nie mogli się $\mathrm{z}$ niego wydostać. Piekło to stan duchowy, naznaczony przez martwote, co wielokrotnie Pilch pokazuje u swoich bohaterów. Towarzyszą im uczucia bezradności, osamotnienia i opuszczenia. W tę sytuację wchodzi Chrystus, by wyciagnąć człowieka $\mathrm{z}$ infernalnej pustki.

Wychodziłem na powierzchnię coraz rzadziej, powracałem pod powierzchnię coraz częściej, powracałem tu nałogowo, powracałem tu permanentnie, powracałem tu natarczywie, aż w końcu najwyraźniej pisany mi los życia pod powierzchnią dopełnił się i zostałem tu sensu largo... ${ }^{19}$

Podkreślony przez autora znak powierzchni jest niezwykle istotny dla wprowadzonej tu perspektywy chrzcielnej. Wspomniana sadzawka, do której zstępuje katechumen, zakrywa go w całości, by ten mógł pogrążý się w sposób widoczny w „wodach śmierci”, a następnie być obdarowany „nowym życiem”. Dla Pilcha rzeczywistość „wód śmierci”, w języku biblijnym symbolizująca niewolę egipską, ale i piekło, staje się codziennością. Przebywanie w stanie permanentnego utrapienia traktuje on jako rodzaj kary, z którego może go wyzwolić już tylko pisanie. To właśnie ów akt przekształcenia utrapienia czy udręki w nowo stworzone dzieło jest dla bohaterów momentem metanoi - autentycznego nawrócenia, czyli doświadczenia przejścia ze śmierci do życia.

Trzeba też zauważyć tak charakterystyczną dla prozy Pilcha postawę cynika, która w samej swej istocie wydaje się sprzeczna z pokorą wpisaną w kenotyczną drogę schodzenia.

Wybrałem medycynę, choć pociagała mnie literatura. Wybór, rzecz jasna, nietrafny, choć nie znaczy to, iż gdybym nie wybrawszy medycyny, wybrał literaturę, byłoby lepiej. W literaturze - bez wątpienia - również niczego bym nie osiagną ${ }^{20}$.

A jednak ta towarzysząca refleksji nad sobą autoironia, która nieprzerwanie pomniejsza znaczenie samego autorstwa czy podważa rolę stwarzania tego, co nowe, wreszcie - która podszyta jest nieufnością do własnej mądrości i władzy, jaką daje pisanie, staje się porządkiem ogołacania. Jak zaznacza Pilch na pierwszej stronicy swej ostatniej powieści:

Bo starość to ho, ho! Sam destylat ironii. Najprzód jej nie ma, i to długo nie ma. A potem jak już jest, to jest. Krótko i intensywnie - pękanie tętniaków i gnicie węzłów chłonnych idzie raz-dwa. [...] Niektórzy powiadają, że miłość też jest ironiczna. W moim wydaniu na pewno. [Z 9] 
Bohater powieści Zuza albo czas oddalenia od początku ma świadomość ironicznego wymiaru sytuacji, kiedy musi wpisać się w kulturową rolę mitycznego satyra, bałamucącego młodą nimfę, lub w lekko sprofanowany we współczesnym kontekście obyczajowym obraz starszego mentora (może nawet Pigmaliona) i młodziutkiej - choć nie tak niewinnej - protegowanej (Galatei). Cynizm przenika się ze strachem, śmieszność $z$ upokorzeniem.

Za tą nieco zabawną grą słów: kynos-kénōsis, kryje się jakaś dodatkowa wartość, na pierwszy rzut oka zupełnie niewidoczna. Kynos, czyli pies, od którego to wyrażenia bierze początek filozofia cyników ${ }^{21}$, jest wszak w tradycji semickiej najbardziej godnym pogardy stworzeniem. Psy jako zwierzęta żyjące w stadach, nie mające swego pana, karmiły się tym, co wyrzucano poza mury miasta. W znaczeniu przenośnym psy były obrazem nieczystości, reprezentowały grzechy nierządu i rozpusty, czyli zwiąane ze sprawami cielesnymi, zewnętrznymi ${ }^{22}$. Na ciekawy trop można trafić podczas lektury 1 Księgi Samuela $(17,43)$, w której pies symbolizuje upokorzenie, a zatem staje się figurą kenotyczną. Zresztą wątek ten (pokory, uniżenia) odnajdujemy także w scenach, kiedy psy liżą wrzody na ciele Hioba dotkniętego trądem, oraz w podróży Tobiasza. Czy można więc w postawie cyników doszukiwać się właśnie kenotycznego wymiaru ich etyki? Czy istotnie nie w cynizmie Pilcha ukrywa się najgłębsza prawda o zejściu do piekieł własnej egzystencji, gdy stwierdza on, że we wszystkich poczynaniach: od twórczości literackiej po zdobycze erotyczne, dominują klęska i pesymizm, a tryumfy w tej materii są rzadkością?

\section{Czy za pisaniem kryje się odkupienie?}

Ten niewielki fragment:

wstępujemy w krainę zmyślenia. Słowo jest zmyśleniem, ciało jest zmyśleniem, początek jest kłamstwem. Wielka miłość na zgliszczach zrodzona może być prawdą? [Z 67]

mógłby z powodzeniem stanowić motto dalszych rozważań. Niemal od samego początku przygody literackiej Pilch buduje postać swego bohatera - pisarza, który zmaga się nie tylko z poczuciem przegranego życia, ale i z frustracją, wynikającą $\mathrm{z}$ jego własnej nieudolności.

Boże mój, nie wzywam Twego imienia na daremno, mój ewangelicki Boże Mikołaja Reja i innych protestantów zasłużonych dla kultury narodowej, Boże mój, Ty jeden wiesz, ile trudu i zachodu kosztowało mnie bezskuteczne powoływanie tej sztandarowej grupki do istnienia ${ }^{23}$.

Zakorzenione w zachowaniu bohatera sztuczność, poza, udawanie, do których on sam ma dystans ironiczny, jako spadkobierca nowoczesności pozostając nieufny wobec każdej z przyjmowanych przez literaturę form, są usytuowane w napięciu między kłamstwem (moralność) a zmyśleniem (sztuka).

21 Psami nazwano cyników $\mathrm{z}$ powodu właściwego im zwyczaju publicznego załatwiania wielu potrzeb, również fizjologicznych.

22 Zob. F. Rienecker, G. Maier, Leksykon biblijny. Red. nauk. wyd. pol. W. Chrostowski. Przeł. D. Ir mińs ka. Uzup. przekł. J. Kru c zyń ska. Warszawa 2001, s. 608.

23 J. Pilc h, Wyznania twórcy pokatnej literatury erotycznej. W: Wyznania twórcy pokatnej literatury erotycznej, s. 162. 
Wszystko mianowicie może być kłamstwem. Wypiszcie tę prawdę sprayem na wszystkich ścianach, wypalcie rozżarzonym metalem na wszystkich deskach, wydrapcie drutem na obu potylicznych płatach. Do was mówię, koneserzy płatnej miłości - wszystko, co kupujecie, może być kłamstwem, każdy biust, każda noga, każda fryzura może być kłamstwem, każda godzina, na którą się umawiacie, może być kłamstwem, każda opowieść, którą usłyszycie, może być kłamstwem, każdy pocałunek jest kłamstwem. [Z 66-67]

Kłamstwem, a zarazem zmyśleniem, efektem imaginacji jest Zuza. Spod powierzchni opowieści wyłania się odarty z politury niedopowiedzeń obraz prawdziwych relacji między starszym mężczyzną a prostytutką, której ten płaci za usługi. W kilku momentach przyznaje on: „Uboczne, a niechciane skutki branych przeze mnie leków, owszem, bywaja psychiatryczne - zdarzają się zaburzenia, majaczenia, urojenia czy nawet olśnienia”. I właściwie to „Zuzy nie ma” (Z 86).

„Wszystko jest zmyśleniem”, zdaje się mówić narrator, narzekając na pamięć. Żyjemy w rzeczywistości stworzonej przez autorów programów telewizyjnych, powielamy wzorce, schematy, śnimy czyjeś sny, tak bardzo przypominające nasze własne marzenia i pragnienia. Zuza niewatpliwie jest zarazem takim pragnieniem, fantazmatem i fetyszem dojrzałego mężczyzny. Nic zatem dziwnego, że w relacji między bohaterem a młodą dziewczyną odbijają się modernistyczne napięcia: między Erosem a Tanathosem, sacrum a profanum czy duszą a seksualnością.

Jako uczeń późnej nowoczesności Pilch zdaje się wierzyć jeszcze w pisanie, rozumiane jako coś na kształt terapii lub jako pewnego rodzaju przeżycie mistyczne, które może człowieka wyprowadzić z „wody śmierci”. Bohater powieści Zuza albo czas oddalenia wyznaje: „Zdarzają mi się dawne przebłyski, dominuje pustka. Niezwłocznie zapisuję (piórem w brulionie) byle jakie przygody Zuzy" (Z 75).

Zapisywanie jest bowiem odciskaniem śladów, zaznaczaniem swojej obecności, która w momencie odczytywania już nie istnieje. Ponieważ pismo oderwane od pióra, od ręki czy wreszcie od osoby kierującej tą dłonią staje się znakiem nieobecnego. Antropologia pisma wielokrotnie podkreśla specyfikę tej sytuacji, w której świadomość trwałości zapisanego przekazu uintensywniona zostaje przez przekonanie o możliwości przekształcania samej treści ${ }^{24}$. Jeśli bowiem forma (dzięki zapisowi) nie wymaga już takiej uwagi ani troski o zapamiętanie charakterystycznej struktury, wolno ingerować w dzieło parafrazując je, streszczajacc, redukując lub rozbudowując. W związku $\mathrm{z}$ tym pismo stało się technologią, która umożliwiła zmianę, otworzyła drzwi zmyśleniom, wychodzącym poza utrwaloną formę.

Jeszcze dalej w swych rozważaniach idzie Walter Ong, przywołujący konstatacje Platona z Fajdrosa, kiedy stwierdza, iż właściwością pisma jest sztuczność - tzn. coś nieludzkiego, udaje ono i stawia poza umysłem to, co może istnieć tylko w sferze myśli ${ }^{25}$. Ta nieludzkość pisma wydaje się niezwykle bliska śmierci w rozumieniu Platona, nosi bowiem znamiona uprzedmiotowienia i zniszczenia. Zapisany

Zob. J. D o ma ń s ki, Tekst jako uobecnienie. Szkic z dziejów myśli o piśmie i książce. Warszawa 1992, s. 19.

25 W. J. O ng, Pismo a struktura świadomości. Przeł. M. P ę c z a k. „Przegląd Humanistyczny” 1988, $\mathrm{nr} 4 / 5$. Pomijam w tym miejscu mniej istotne konstatacje na temat niszczenia pamięci przez pismo, braku odpowiedzi ze strony tekstu pisanego czy braku możliwości obronienia się przez nie przed czytającym, bierności itp. 
tekst, który nie odpowiada, jest bierny, niemy wobec stawianych mu pytań, w rzeczywistości jawi się jako martwy. Według Onga wynika to $z$ dystansu tworzonego między piszacym a tekstem oderwanym od swego podmiotu. Zapis pozostaje czymś zewnętrznym (poza egzystencją), a zatem czymś kompletnie martwym, do momentu, kiedy nie zetknie się $z$ odbiorca gotowym włączyć go we własne doświadczenie - ożywić poprzez odczytanie w swoim kontekście życiowym.

Dzięki oddzieleniu podmiotu od przedmiotu poznania pismo wydobywa na jaw introspektywność, jak nigdy przedtem otwierając psychikę nie tylko na obiektywny, zewnętrzny świat, tak różny od niej samej, lecz także na jej własne przeciwstawione obiektywnemu światu wnętrze ${ }^{26}$.

Pilch - pisarz, każe swoim bohaterom pokładać nadzieję w tym procesie. Sytuując ich w napięciu panującym między namiętnością do kobiet a pasją do literatury, przywołuje tu Barthes’owską koncepcję pisania jako uwodzenia. Czym ono jest?

Uwodzenie jest z pewnością grą bez żadnej transcendencji, spłaszczeniem istnienia, zamaskowaniem rozpaczy. Rozpaczy nienasycenia, dla którego spełnienie jest złem koniecznym [... $]^{27}$.

Mechanizm uwodzenia to nieustanne odwlekanie uobecnienia, odsuwanie w czasie, nieskończone nienasycenie, a zarazem uczucie pogłębiającego się pragnienia. W mechanizmie „u-wodzenia” skrywa się oddalenie, odseparowywanie: miłości od cielesności, kobiety od domu, autora od dzieła. Rdzeń „wodzić” konotuje ruch na zewnątrz: od „ja” do „poza ja”, na bok, na stronę, ale także wyprowadzenie $\mathrm{w}$ pole. $\mathrm{W}$ tym słowie skrywa się również potencjalne wyrażenie „wodzić na pokuszenie", a więc uwodzenie właśnie. Ów ciemny, niemoralny gest daje się opisać w kategorii pozoru czy kłamstwa. Uwodzenie jest gra sztuczności, udawaniem, a zatem mechanizmem, który ma na celu fałszowanie prawdy i skrywanie rzeczywistych intencji poprzez skupienie uwagi na tym, co błyszczące, powabne, atrakcyjne dla wzroku. Bohater Pilcha wyznaje:

Czegóż ja nie robiłem! Zapisałem tony papieru, raczyłem się kawą, koniakiem, winem. Biurko setki razy przesuwałem spod okna pod ścianę i z powrotem pod okno. Wstawałem o bladym świcie i ślęczałem do późnej nocy. Papierosy paliłem. Przebierałem się nieustannie, bo wydawało mi się, że mój wygląd zewnętrzny ma wpływ na rodzaj prowadzonej przeze mnie narracji28.

Taka właśnie jest Zuza - uwodząca swym wyglądem, wodząca na pokuszenie, wystawiająca na próbę i w równym stopniu nieprawdziwa, wymyślona co namacalna.

Zuza to figura pisania, która powołuje do istnienia bohatera-narratora. Oto słowa Pilcha $z$ jego wczesnego opowiadania:

Nastał rok 1980, ja zaś nadal nie byłem pisarzem. Byłem co najwyżej postacią literacką, wyrazistą zapewne, lecz drugoplanową. Byłem postacią literacką, choć tylko Pan Bóg wspomniał o mnie mimochodem i między wierszami swego dzieła ${ }^{29}$.

Ibidem, s. 173.

M. P. Markowski, Występek. Fragmenty o pisaniu. W: Występek. Eseje o pisaniu i czytaniu. Warszawa 2001, s. 27.

Pilc h, Wyznania twórcy pokatnej literatury erotycznej, s. 162.

Pilch, Kraków, s. 22. 
Zuza jest odbiciem istoty pisania i zarazem w niej odznacza się twarz bohatera. Ten akt stanowi zawsze wychodzenie poza samego siebie, tytułowy „czas oddalenia”, przekraczanie granicy własnego „ja” ku innemu, gest rezygnacji, odarcia właśnie, rodzaj kenozy - oddania się komuś, kto zechce przyjąć:

Pisząc, oddalam się od świata pod pozorem jego przyjmowania, zdradzam jego potrzeby, chcąc im sprostać i tym samym włączam się w nieskończoną gromadę chwalców niewierności ${ }^{30}$.

Stąd Pilch wielokrotnie zestawia sytuację bohatera-literata $\mathrm{z}$ najstarszym zawodem, jakim para się Zuza. Tak jak żadna prostytutka nie całuje nigdy w usta, tak literatura nigdy nie oddaje się do końca, na własność, ale pozostaje niepochwycona w tym u-wiedzeniu. Podobnie jak pisanie - Zuza egzystuje w świecie zdrady, obecność dziewczyny w życiu bohatera stanowi apoteozę niewierności, tak samo jak gest pisania jest zawsze uprawianiem nierzadu, oddaniem siebie innym.

$Z$ tym tropem wiąże się jeszcze jeden, konotowany przez sytuację kenotycznego schodzenia, które realizuje się w akcie kreacji - mit o Orfeuszu i Eurydyce. Orfeusz wyraża to, co w poezji najbardziej wzniosłe i piękne. Jego lira, nastrojona na wzór apolliński, wpisana w naturę, oddaje porządek świata. Sztuka tworzona w duchu Apollona koryguje niedoskonałości rzeczywistości, zakrywa prawdę, zasłania i uwodzi. Jest to sztuka miary i harmonii, która podnosi akt kreacji do rangi zbawczej ${ }^{31}$. Z takim przekonaniem Orfeusz przekracza bramy Hadesu, by odzyskać ukochana Eurydykę. Ta, uciekając przed Aristajosem, który chce ją zgwałcić, następuje na węża i umiera od ukąszenia. Orfeusz schodzi więc do Tartaru, wierzace, że lira apollińska ma moc wyprowadzenia życia z krainy śmierci. Wiara w zbawczą siłę sztuki zostaje skonfrontowana $z$ bezsensem śmierci, dlatego droga Orfeusza do Hadesu jest kenozą. Poeta tracki podąża w kierunku bezmiernego doświadczenia głębi prawdy o sobie, tylko w ten sposób może powstać sztuka autentyczna. Orfeusz wyjdzie stamtąd zarazem jako przegrany (jego apollińska wiara w moc zbawcza sztuki zostanie zachwiana, wszak Eurydyka nie powróci z Hadesu), jak i zwycięski (dowie się, że pozór i fałsz, jakimi operuje piękno, nie dają odpowiedzi na pytanie o sens, o istotę życia). Eurydyka okazuje się tym, kto przekracza granice sztuki, jest esencją życia, nieosiągalną, ale prawdziwa, która warunkuje wyprawę w głąb siebie, w przepastną, ciemną noc swego „ja”.

Jeśli się czyta powieść Zuza albo czas oddalenia według tego klucza, pisanie jawi się jako proces odsłaniania prawdy, a nie jej korygowania czy zakrywania. Bohaterka Pilcha budzi zachwyt i pożądanie, stanowi zapowiedź rozkoszy, lecz podobnie jak sam gest pisania - znajomość z Zuzą naznaczona jest cierpieniem niespełnienia, nieposiadania.

Nie da się napisać historii miłosnej bez wejścia w drugiego człowieka. Bez pozbawienia go wolności.

31 Zwraca na to uwage F. N i et z s c he (Narodziny tragedii albo Grecy i pesymizm. Przekł., przedm. B. B a r a n. Kraków 1994), przeciwstawiając apollińskie piękno sztuki dionizyjskiemu nadmiarowi i chaosowi. Apollińska idea piękna próbuje zasypać przepaść, która pojawia się między prawdą, czyli tym, co postrzegalne za pomocą zmysłów czy doświadczane przez człowieka, a jej pozorem. U podstaw jednak takiego rozumienia sztuki leży próba zafałszowania rzeczywistości, dlatego sztuka staje się sakramentem zbawienia dla jednostki, choć daleka jest od życia. 
Spałem z Zuzą, ale jej nie miałem. Miałem Zuzę, ale w istocie nie z Zuzą, lecz z jej ciałem obcowałem. Byłem w niej - nie byłem z nią. Byłem tak blisko, że bliżej nie można, w istocie trzymała mnie - jak zawsze - na dystans. [Z 126]

Zakorzeniony w relacji z Zuzą „czas oddalenia” jest w rzeczywistości metafora aktu pisania. Towarzysząca temu gestowi kenoza (uwodzicielska klęska za klęską, pustka ujawniająca się w rzekomych ślicznotkach, bycie zakładnikiem własnych infantylnych wyobrażeń itp.) wraz z całym bagażem niepięknych zachowań, fizjologią ludzkich ciał, w niczym nie przypominających tych bezwonnych, wydobytych z biologicznego uwikłania, jak na ilustracjach pism dla dorosłych, wyciaga na wierzch prawdę o sobie samym. „To jest i tylko to jest ocalenie”32.

\author{
Abstract \\ ADAM REGIEWICZ Jan Długosz University, Częstochowa \\ ZUZANNA AND AN OLD MAN KENOTIC DIMENSION OF JERZY PILCH'S WRITING
}

Jerzy Pilch's writing is normally associated with pastiche, parody, postmodern play with convention. His latest mini-novel, in its title referring to the Biblical tradition, suggests some other trope of reading. When read from a kerygmatic interpretive perspective, Pilch's text reveals to its audience a totally different dimension of writing. The protagonist, often putting on a mask of a cynic, conceals a deeperkenotic-dimension of his personality. Self-emptying and humility (kenosis), common to Diogeneian School and Christian tradition, points at the importance of crisis as on the seminal existential experience which leads to liberation.

32

Cz. Miło s z, Przedmowa. W: Wiersze wszystkie. Kraków 2011, s. 143. 